\title{
Perceptions of dental students regarding dentistry, the job market and the public healthcare system
}

\author{
Percepções dos estudantes de odontologia sobre a Odontologia, \\ Mercado de trabalho e Sistema Único de Saúde
}

Simone de Melo Costa ${ }^{1}$

Marise Fagundes Silveira ${ }^{2}$

Sarah Jane Alves Durães ${ }^{3}$

Mauro Henrique Nogueira Guimarães de Abreu ${ }^{4}$

Paulo Rogério Ferreti Bonan ${ }^{5}$

\footnotetext{
${ }^{1}$ Departamento de

Odontologia, Universidade

Estadual de Montes Claros. Avenida Dr. Ruy Braga sem $\mathrm{n}^{\circ}$ Campus Darcy Ribeiro, Vila Mauricéia. 39401-089 Montes Claros MG. smelocosta@gmail.com

${ }^{2}$ Departamento de Ciências Exatas, Universidade

Estadual de Montes Claros.

${ }^{3}$ Departamento de

Educação, Universidade

Estadual de Montes Claros.

${ }^{4}$ Departamento de

Odontologia Social e

Preventiva, Faculdade de

Odontologia, Universidade

Federal de Minas Gerais

${ }^{5}$ Departamento de Clínica

Odontológica e Social,

Universidade Federal da

Paraíba.
}

\begin{abstract}
The scope was to analyze the perceptions of dentistry students at the State University of Montes Claros, Brazil, regarding dentistry, the job market and the public healthcare system. For this, a triangulation method was employed, using a self-administered questionnaire and interviews. The quantitative data were submitted to univariate and multivariate analysis, using Poisson regression, where $p<0.05$. Content analysis was used for the qualitative data. The majority reported expecting to obtain work in the public healthcare system, stated that the dentistry course prepares students for this market as the curriculum integrates both teaching and service, reported being in favor of greater experience in the public healthcare system and said they would not take classes in Public Health if they were optional. Contact with the social context through teaching/service integration in the advanced semesters of the dentistry course appears to contribute to the development of new professional skills for working in the public sector. However, the students' perceptions revealed contradictions, considering the low value they attributed to the classes on Public Health and their perception of the public system as a residual job option.
\end{abstract}

Key words Dentistry, Dental students, Perception
Resumo O objetivo foi analisar as percepções dos estudantes do Curso de Odontologia da Universidade Estadual de Montes Claros, Unimontes, quanto à Odontologia, ao Mercado de trabalho e ao Sistema Único de Saúde (SUS). Optou-se pela triangulação de métodos utilizando questionário autoaplicado e entrevista. Os dados quantitativos foram submetidos à análise univariada e multivariada pela Regressão de Poisson considerando $p<0,05$. Para abordagem qualitativa utilizou-se a análise de conteúdo. A maioria destacou o SUS como expectativa de trabalho, afirmou que o Curso capacita para o mercado uma vez que a proposta curricular integra ensino-serviço, afirmou ser favorável à maior vivência no SUS e não faria as disciplinas da Saúde Coletiva se fossem optativas. Concluiu-se que, o contato com o contexto social através da integração ensino-serviço, nos períodos avançados do Curso, contribuiu para desenvolver novas competências e habilidades profissionais para o trabalho no setor público, já que a Saúde Coletiva e os princípios do SUS é que embasam essa integração. No entanto, há contradições nas percepções dos estudantes, que pouco valorizam as disciplinas de Saúde Coletiva, as quais embasam a integração ensino-serviço.

Palavras-chave Odontologia, Estudantes de odontologia, Percepção 


\section{Introduction}

The Brazilian public healthcare system is a universal system that ensures the right to healthcare. The Brazilian public healthcare system emerged following an intensive process of renegotiation of national healthcare services proposed in the period following the exit of the military dictatorship ${ }^{1}$.

In Brazil, the public healthcare system is the largest employer in terms of healthcare and dentistry $^{2}$. The significant increase in hiring in the public healthcare system has influenced the education of healthcare professionals, suggesting changes in the content and knowledge offered in dentistry courses, with an emphasis on public healthcare as a promising job market. Furthermore, a number of studies carried out in Brazil have identified a need for education based on community needs, proposing the development of sensitivity to perceptions in the education of healthcare professionals as well as solutions to collective demands ${ }^{3-6}$.

The new healthcare organization model has led to the increasing inclusion of dentistry in the public sector. Therefore, dental students must have experience in other practice settings, in addition to activities within the University, to allow contact with the real needs of the population ${ }^{3,4,7}$. The largest employer of dentists is the public sector, which contributes $72.86 \%$ of total employment ${ }^{8}$.

For this goal, the Dentistry Course of the State University of Montes Claros (Unimontes) (Minas Gerais, Brazil) is participating in the Healthcare Professional Reorientation Program established by the Ministries of Education and Health as a means to train healthcare professionals to meet social demands and work within the operations of the public healthcare system 9 .

The Unimontes course was begun in 1997 and aims to contribute towards breaking down an education process which previously concentrated on technical aspects. The course emphasizes an integrated approach to promote health and clinical actions at the individual and collective level. The promotional activities involve education, epidemiological surveillance and health, multidisciplinary actions, and participation in Family Health. Clinical interventions involve preventive care, and restorative and surgical treatment in different life cycles. The program involves training for an integrated strategy of oral health promotion and rehabilitation on both an individual and collective level. The aim is to train general dental professionals in practices that are coherent, with a reori- entation of the healthcare model based on primary care and teaching/service integration.

The reoriented model of the public health service from the Family Health Strategy indicates that public actions will contribute to a reversal of the prevailing logic of funding and provision of curative services, and has influenced the recent changes in the training of human resources ${ }^{10}$. It is noteworthy that dentistry saw no significant change in employment, reflecting a saturation of the abrupt expansion of the private and public market with the implementation of national policy on oral health.

An understanding of social representations as perceived by students may contribute to this discussion, addressing the thinking of symbolic production established in a social-historical context by explaining attitudes, concepts and actions stemming from daily living and considering the relationship between the particular and the universal. Thus, an individual is seen as a social entity - a living symbol of the group he/she represents and may be addressed as a generic subject ${ }^{11}$.

In Brazil, few studies have assessed the perceptions of students regarding the job market, public healthcare system and education in dentistry, despite the possible association between these topics. Thus, the aim of this study was to analyze the perceptions of dental students from Unimontes (Minas Gerais, Brazil) regarding dentistry, the job market and the public healthcare system.

\section{Methodology}

The Triangulation Method was used, as individual methods alone do not fully address the issues raised in an investigation, due to the limitations of closed models. Triangulation means using more than one approach to address the same issues, thereby improving the reliability and consistency of the results ${ }^{12,13}$. The present study employed qualitative and quantitative approaches. Two or more methods may be used in conjunction with theory to look at the same issue from different perspectives ${ }^{14}$.

The qualitative method sought to understand and explain the dynamics of social relations. As the teaching of dentistry at the Unimontes is carried out over a five-year period, four students from each year were randomly selected by year and gender for the interview, comprising a sample of twenty students, identified by the following criterion: interviewing a number of individu- 
als to allow a certain recurrence of information. The interviews were recorded and transcribed for subsequent content analysis using the theme analysis method. The data were organized into themes and analyzed in light of the available literature and objectives of the study ${ }^{15,16}$.

A guide was used for the interviews in order to ensure direction was given to the conversation, but without interfering in the informants' thought process. The guide presented four context units: Student Profile, Perception of Dentistry, Perception of Job Market and Perception of the Public Healthcare System. A pilot study was carried out involving five students from different semesters. In order to ensure the anonymity of each student, the statements were coded with the letter 'S' (student) followed by a number.

For the quantitative approach, a self-administered questionnaire consisting of 13 closed-ended items was used for data collection, addressing Student Profile, Perception of Dentistry, Perception of Job Market and Perception of the Public Healthcare System. The total number of students enrolled in the second semester of 2007 was 237. In a classroom setting, all participants were given information on the survey distribution as well as the number and type of questions, topics covered and the assurance that anonymity would be maintained. Although the questionnaire employed was not formally validated, a pilot study was previously carried out to test students' understanding of the instrument addressing perceptions of dentistry, the job market and the public healthcare system. In addition, the test-retest model was used to evaluate responses from the same respondents on two different occasions. To do so, the questionnaire was administered to 30 students a second time. Agreement between responses on the two separate occasions was measured using the Kappa coefficient, with values ranging from 0.80 to 1.0 , thereby demonstrating a high degree of reproducibility in the responses. A questionnaire is more reliable when able to reproduce the same responses on different occasions ${ }^{17}$. Thus it is unlikely that the students had difficulty in understanding the questionnaire, which was divided into four parts: Student Profile; Perception of Dentistry; Perception of Job Market; and Perception of the Public Healthcare System. The following were the dependent variables: 'Is the job market currently favourable to dentists?'; 'Are you in favour of more teaching activities in the public healthcare system?' and 'Do you feel prepared to work in the public healthcare system?'
The independent variables were the socio-demographic variables of the student profiles dichotomized: course semester [1st to 5 th semester (initial) and 6th to 10th semester (final)]; age (17 to 21 and over 21 years); place of origin [northern state of Minas Gerais (where Unimontes is located) and other regions]; and gender (male and female).

The answers were processed using the Statistical Package for Social Sciences (SPSS for Windows ${ }^{\circledR}$, version 15.0$)$. Statistical analysis was performed using mean, standard deviation, relative frequency and absolute frequency. Univariate and multivariate analyses were carried out using the Poisson regression model, with robust variance in order to estimate the prevalence ratio (PR) with a 95\% confidence interval (PR95\%CI), and the Wald test. These analyses were employed in order to compare dependent variables with socio-demographic variables. For each dependent variable a multivariate model was constructed. Independent variables that were associated with an outcome at $\mathrm{p}<0.20$ were retained if $\mathrm{p}<0.05$. Analysis of Variance was carried out in order to compare the student's abilities in primary care among different course semesters. Statistical significance was set at $\mathrm{p}<0.05$.

The project was submitted to the Ethics Committee for Research on Human Subjects of the Unimontes.

\section{Results / Discussion}

The quantitative approach proved more productive for some questions. However, it was often insufficient for the comprehension of context in situations that could not be expressed in numerical values. In such cases, a combination of the quantitative and qualitative approaches was used to obtain a complex reflection, in which both approaches were valued in a complementary fashion ${ }^{18}$. The results were presented in three sets of findings: Demographic Characteristics and Perception of Dentistry; Perception of the Job Market; and Perception of the Public Healthcare System.

\section{Demographic Characteristics and Perception of Dentistry}

Two hundred and twenty nine (response rate $=96.6 \%)$ students participated in the quantitative study. Of these, $62.4 \%$ were female. This finding corroborates a previous study carried out at Unimontes, which found the phenomenon of 
feminization in dentistry ${ }^{19}$. A total of $46.3 \%$ were students in the first through fifth semester and $53.7 \%$ were in the sixth through tenth semester. Age ranged from 17 to 41 years; $83.0 \%$ were 24 years of age or younger $(22.39 \pm 3.01)$. The majority had been born in the state of Minas Gerais (MG) $(94.3 \%)$ and $52.4 \%$ had been born in the city of Montes Claros. This aspect may facilitate the implementation of the Educational Project in dentistry at Unimontes, as the project was conceived to treat the oral health of the Brazilian population, with an emphasis on the regional needs of the northern portion of the state of MG, which is an underdeveloped region.

When asked about the main task of dentistry, the majority $(88.6 \%)$ stated prevention of disease and promotion of oral health; $10.0 \%$ stated the treatment of diverse diseases of the oral cavity; and just $1.4 \%$ stated caring for the aesthetics of the teeth. Thus, it may be said that dentistry is perceived as a new practice directed towards health promotion, which requires the incorporation of new knowledge, cultural changes and a commitment to public management ${ }^{20}$. In the interviews, the students reported having had a distorted view of dentistry prior to entering the Unimontes Dentistry Course, just as society has in general - a reductionist, tooth-centric view.

Everyone has a very limited view of dentistry, as I used to have [...], that a dentist is only for performing restorations or fitting dentures. (S16)

As a social group, the university influences the perceptions of students and changes their social representations. Interaction with professors and classmates, along with other social influences, leads to the development of a group identity. The individual perception of events is dependent upon the group to which the individual belongs ${ }^{21}$. It can therefore be stated that the dentistry course provides a new view of the profession, addressing a broader concept of healthcare, in which health promotion and the prevention of disease are stressed. This finding is in agreement with the teaching strategies of the Unimontes course, as well as the education policies of the Ministries of Education and Health.

A simple, pragmatic, common view of a utilitarian, scientific and individual practice characterizes the fragmented representations of dentistry. In the beginning, manual tasks, extractions and replacements predominated. Thus, dentistry was associated with a more cosmetic than therapeutic function - with 'artisan' or 'commercial' work - and therefore was held in low social esteem for not appearing to have a relationship with science ${ }^{22}$. The interviews revealed that the students criticize the tooth-centric view, which, once again, reinforces the role of professional education in the perspective of forming a differentiated view and breaking from the fragmented model that still reigns in Brazilian society.

\section{Perception of the Job Market}

The majority of students $(\mathrm{n}=204 ; 89.0 \%)$ expect to work in the public sector. Of these students, only $17(8.3 \%)$ stated it as their only work expectation. However, most (56.0\%) would dedicate eight hours a day to public service. This reinforces the idea that the public sector is perceived as a possibility for entering the job market. The qualitative approach identified that, prior to entering the university, the view of the job market was limited to private practice.

The idea I had before starting the course was that I would work for myself after graduating. Later, when I got here, I realized that the situation was entirely different. We are going to work for the Family Health Program; [...] there is a large job market for us. (S1)

In Brazil, the expectation is to improve health indicators following the reorganization of primary care services and the introduction of the National Primary Care Program - the Family Health Program (FHP) ${ }^{1}$. Through the FHP, the Brazilian public healthcare system is perceived as a field of broad scope and has contributed towards allowing healthcare professionals to join the job market. There are also perceptions that an education in health should be in harmony with the public healthcare system.

A University has to inform students regarding this part of the public healthcare system, the FHP... explaining what it is. (S15)

The FHP was established by the Brazilian federal government and its main feature is multiprofessional healthcare, with an emphasis on the family approach, in-home visits and the facilitation of access to services. The FHP has broadened the possibilities of work positions during a difficult time for dentistry, with a saturated job market in urban centres. On the other hand, only 13 students (5.7\%) stated that the private sector was the only setting in which to operate. The reduced opportunities for exercising the profession as a private enterprise affect undergraduates and their expectations regarding work. The implantation of public services, firms and associations has changed the job market ${ }^{23}$. For instance, the growth in jobs in the public sector has been much 
greater than that in the private sector. The public sector is currently the largest employer in healthcare $^{2}$. Thus, technicist training directed only toward the private sector carries with it difficulties regarding entering the job market.

Analyzing the perception of the public healthcare system, both positive and negative views are encountered. Manifestations of a willingness to work in public healthcare for reasons of social commitment were perceived.

We have learned a lot here about the public healthcare system [...]; one needs to have such knowledge in order to change public healthcare in Brazil or in any situation one finds oneself. (S19)

However, some see the public healthcare system as a training locus for the acquisition of experience and skills for subsequent professional exercise in a private office.

It would be a good experience to have a job with city hall [...]. I think these are wonderful experiences before you open a private office. (S19)

A previous study found that students sought to gain clinical experience immediately following graduation by working as an employee in the public or private sector ${ }^{24}$. The public healthcare system is identified as a 'way to avoid unemployment' with the lack of prospects in private practice. Thus, the public healthcare system serves as an option for residual work. A study carried out in $1997^{25}$ concluded that, due to difficulties in the job market, the public healthcare system receives professionals who are not adequately prepared from the standpoint of the principles that govern the system.

Many times, it's due to a lack of options [laughs]. Not everybody wants to graduate and work in the public healthcare system. [...] even those who don't want to, end up going into it. (S20)

The triangulation method allowed reflection on the following aspect: the quantitative approach $(89.1 \%)$ revealed a favorable expectation of working in the public healthcare system; however, the qualitative approach revealed that some undergraduates see the public sector only in terms of personal interest rather than being motivated by social aspects of the profession, and they relegate public work to a background position as a residual option - a place for acquiring training and making money in order to invest in a private office. This may explain the low percentage of interest in the public sector as the only work option (7.4\%). However, the public healthcare system is also seen as a sector that exploits the labour of dental surgeons, as well as an inoperative healthcare system.
According to $83.3 \%$ of the respondents, the course trains students for the job market. In the qualitative approach, all interviewees stated that the course favours inclusion in the job market through the teaching/service integration and the FHP.

The curriculum at Unimontes is very favourable. I think it has some things, like materials, that other courses do not have [...], such as the FHP. (S4)

The diversification of teaching/learning scenarios favours integration into the social reality, as it is through these experiences that the learning process is contextualized, integrating experience with reflection and theory with practice ${ }^{26}$. In the view of the interviewees, graduates from Unimontes can easily find a place in the job market. This may be explained by the education model, which emphasizes public healthcare, diversifying practice scenarios with the aim of inclusion in the job market.

The staff members at the public service ask, 'Do you study dentistry at Unimontes?' There is a lot of esteem placed on it [...]. (S19)

The education offered at Unimontes involves a rethinking of attitudes, values and practices associated with healthcare and trains professionals for integrated actions in the promotion and recovery of oral health in both an individual and collective fashion. According to $44.1 \%$ of the students, the job market is not favorable to dentistry. The only variable retained in the multivariate model was the semester of study. An association was observed with the semester of study $[\mathrm{p}=0.007$; PR (95\%CI): 1.50 (1.12-2.02)] (Table 1). The undergraduates gained a broader vision throughout the course regarding the possibilities of exercising their profession, as the proportion of unfavorable responses to the job market in dentistry among the students in the first to fifth semesters was 1.5-fold greater than that of the students in the sixth to tenth semesters.

There are different perceptions regarding the job market in dentistry. Negative perceptions of a saturated, competitive, trivialized market and disloyal competition explain the responses of $44.1 \%$ of the students. Contrarily, positive perceptions of an ample market, the employability of recent graduates and the broadening of oral healthcare in the public sector explain the response of the majority (55.9\%), who perceive the market as favorable.

Regarding postgraduate courses, $96.1 \%$ intend to study a specialty for between one and 60 months, $79.6 \%$ of whom cited up to 12 months. A previous study found that $69.4 \%$ of interviewees 
considered a postgraduate course indispensable ${ }^{27}$. The interviews revealed the perception that qualification should be extended through a postgraduate program and that professional training and versatility were cited as criteria for having a competitive edge in the job market.

When asked about their intended field of specialization, only $12(5.5 \%)$ students cited Collective/Public Health. The lack of interest in this field is interesting, considering the understanding that the public healthcare system has broadened the job market in dentistry. A number of arguments may explain this results: current inclusion in the public healthcare system does not require specialization in Collective/Public Health, as graduating the dentistry course is sufficient; specialization in this field does not offer the status or financial gains of other specialties; or working in the public healthcare system continues to be seen as a way to complement income, with no compensation for investing in qualification for this field.

\section{The Brazilian Public Healthcare System}

Table 2 lists the activities required for performing primary care in the public healthcare system and which the students judged themselves capable of executing. There was an increase in the number of students' abilities in primary care in the advanced semesters of the course (Figure 1). There was a significant difference $(\mathrm{p}<0.001)$ be-

Table 1. Students' perception of job market; univariate Poisson regression

\begin{tabular}{|c|c|c|c|c|c|}
\hline \multirow[b]{2}{*}{ Variables } & \multicolumn{4}{|c|}{ Job Market } & \multirow[b]{2}{*}{$\begin{array}{c}\mathrm{PR}(95 \% \mathrm{CI})^{\mathrm{a}} \\
\text { univariate }\end{array}$} \\
\hline & \multicolumn{2}{|c|}{$\begin{array}{c}\text { Favorable to } \\
\text { dentistry }\end{array}$} & \multicolumn{2}{|c|}{$\begin{array}{l}\text { Unfavorable } \\
\text { to dentistry }\end{array}$} & \\
\hline \multicolumn{6}{|l|}{ Semester } \\
\hline $6^{\text {th }}$ to $10^{\text {th }}$ & 79 & $64.2 \%$ & 44 & $35.8 \%$ & 1 \\
\hline $1^{\text {st }}$ to $5^{\text {th }}$ & 49 & $46.2 \%$ & 57 & $53.8 \%$ & $\begin{array}{c}1.54(1.12-2.02) \\
p=0.007^{b}\end{array}$ \\
\hline \multicolumn{6}{|l|}{ Gender } \\
\hline Female & 80 & $55.9 \%$ & 63 & $44.1 \%$ & 1 \\
\hline Male & 48 & $55.8 \%$ & 38 & $44.2 \%$ & $\begin{array}{c}1.00(0.74-1,36) \\
p=0.985^{b}\end{array}$ \\
\hline \multicolumn{6}{|l|}{ Age (year) } \\
\hline 22 and over & 84 & $60.0 \%$ & 56 & $40.0 \%$ & 1 \\
\hline 17 to 21 & 44 & $49.4 \%$ & 45 & $50.6 \%$ & $\begin{array}{c}1.26(0.95-1.69) \\
p=0.112^{b}\end{array}$ \\
\hline \multicolumn{6}{|l|}{ Origin } \\
\hline North of State & 114 & $57.3 \%$ & 85 & $42.7 \%$ & 1 \\
\hline Other Places & 14 & $46.7 \%$ & 16 & $53.3 \%$ & $\begin{array}{c}1.25(0.86-1.81) \\
\mathrm{p}=0.241^{\mathrm{b}}\end{array}$ \\
\hline
\end{tabular}

${ }^{a}$ PR $(95 \%$ CI $)$ - Prevalence Ratio (95\% confidence interval). ${ }^{\mathrm{b}}$ Wald Test tween the averages of the initial $(3.55 \pm 2.40)$ and final $(7.56 \pm 1.48)$ course semesters. Apart from the quantitative analysis, whereas the undergraduates in the initial semesters reported having no knowledge regarding the public healthcare system, students in the more advanced semesters had such knowledge and understood the importance of the public sector in the job market. The students in the final semester understood that the current job market requires a new professional profile, teamwork and a broad view of the concept of healthcare ${ }^{10,28}$.

The public healthcare system does not only involve [...] physicians, but also other healthcare fields, incorporating new activities; it is a process of exchange. (S8)

The work process in the public healthcare system was perceived as a new dimension in the division of professional responsibilities, in which other healthcare professionals besides physicians contribute toward improving the services offered ${ }^{29}$.

Beginning in the seventh semester, the interviews revealed that the form of offering healthcare has also undergone changes. According to the interviewees, through the FHP, the public healthcare system is an attempt to break from the supremacy of the biomedical model. The personal interests of the students did not supersede collective interests of benefits to the general population and its oral health status.

Table 2. Frequency of activities required for performing primary care in the public healthcare system and which the students judged themselves capable of executing

\begin{tabular}{|c|c|c|c|c|}
\hline $\begin{array}{l}\text { Activities in the Public } \\
\text { Health Care System }\end{array}$ & Yes & $\%$ & No & $\%$ \\
\hline 1. Health education & 189 & $83.3 \%$ & 38 & $16.7 \%$ \\
\hline 2. Clinical activities & 141 & $62.1 \%$ & 86 & $37.9 \%$ \\
\hline $\begin{array}{l}\text { 3. Epidemiological } \\
\text { survey }\end{array}$ & 125 & $55.1 \%$ & 102 & 44.9 \\
\hline $\begin{array}{l}\text { 4. Administrative } \\
\text { meetings }\end{array}$ & 99 & $43.6 \%$ & 128 & $56.4 \%$ \\
\hline $\begin{array}{l}\text { 5. Multiprofessional } \\
\text { work }\end{array}$ & 189 & $83.3 \%$ & 38 & $16.7 \%$ \\
\hline $\begin{array}{l}\text { 6. Collective activities } \\
\text { for health promotion }\end{array}$ & 187 & $82.4 \%$ & 40 & $17.6 \%$ \\
\hline $\begin{array}{l}\text { 7. Heading the oral } \\
\text { health team }\end{array}$ & 97 & $42.7 \%$ & 130 & $57.3 \%$ \\
\hline $\begin{array}{l}\text { 8. Planning actions in } \\
\text { the public health }\end{array}$ & 136 & $59.9 \%$ & 91 & $40.1 \%$ \\
\hline 9. Others FHP & 121 & $53.3 \%$ & 106 & $46.7 \%$ \\
\hline
\end{tabular}
activities 


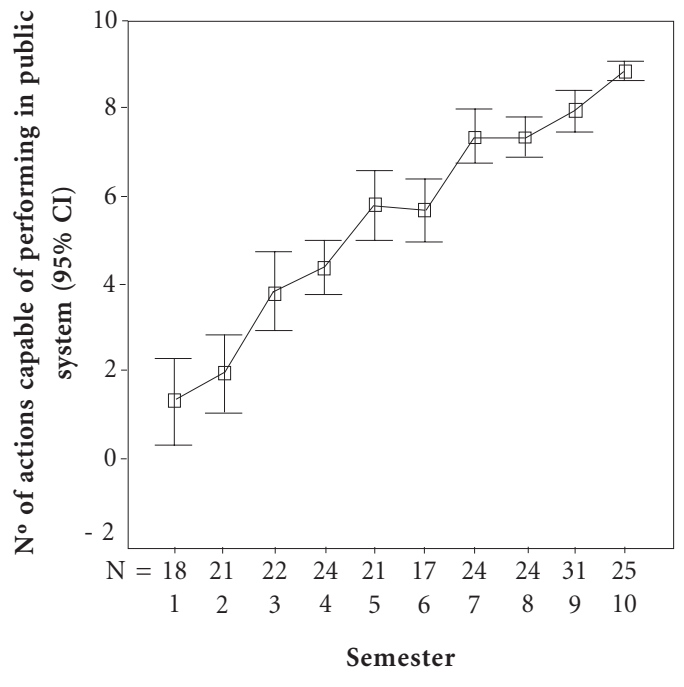

Figure 1. Mean number of activities required for performing primary care in the public healthcare system per course semester.

In order to work well in the public healthcare system and family health, you must believe in the principles of the public system: integrality, equity, universality [...]; you must believe that the public healthcare system is a new, effective proposal that improves healthcare. (S20)

This is an important finding, as it once again stresses the role of higher education institutions in training professionals who are aligned with the new healthcare model and meet the requirements of the current public healthcare system in Brazil. The literature reinforces the importance of such an education, stating that the university should prepare professionals with biological, ethical and social skills, as individuals are the most important resources for producing (or failing to produce) changes in an organization ${ }^{2}$. Beginning with the seventh semester, the interviews reveal that there is a recognition that dentistry needs to take on new roles in the public healthcare system. 'Internship in Family Health', a course which is taught in the seventh semester, could have contributed toward this perception.

We are taught not to have that singular vision of only teeth. We have a more holistic view [...] there is the FHP [...]; we have to demystify this idea of the dentist treating teeth. Regarding the public healthcare system, dentists can participate in orientation, joining teams, doing a number of things and not just treatment - for instance, drafting projects for teams. (S15)

Integrated treatment, addressing prevention through to rehabilitation is an important aspect in healthcare. This point is also made in the $\mathrm{Na}$ tional Curriculum Guidelines, which state that education that places emphasis on the integrality of healthcare allows students to have a more holistic view of patients, as well as to be better able to work in a team, draft projects and communicate effectively ${ }^{30,31}$. From the statement of one student in the last semester, it can be suggested that the course contributes toward an understanding of the role of dentistry in the public healthcare system.

The role is to improve the oral health status of the population [...] working not only in the dental office, not only seeing the mouth, [...] performing prevention, promotion, assessing the existing problems, training community agents to spread concepts, [...] working on a team; not only this, but there is the bureaucratic part of filling out forms, feeding the data into the data system [...]; it's not only care; there is a broader service in the dentist's role in the public healthcare system. (S19)

Another important aspect highlighted by a student in the last semester is the role of transforming society. In order to work in the public healthcare system, it is necessary to acquire new skills, such as understanding the social issues involved in the health/illness process, as patients are social subjects.

You can't speak about healthcare without speaking about dentistry. There has to be a change in concepts - a transformation in society [...]; you cannot accept just going to the public service and making resin and amalgam morning, noon and night [...]; It is very easy to develop technical skills to do that. The hard part is understanding that this patient [...] pertains to a social context and that if everything you do is not accompanied by adequate clinical orientation, this patient will be back in a few days with the same problem or an even worse problem [...]. (S20)

Working with a new healthcare model is not a simple task and requires a differentiated view, as well as a high degree of complex knowledge ${ }^{28}$. In the field of Collective/Public Health, education is interdisciplinary; there is complexity in the object of study, which seeks to understand the determinants of the health/illness process and overcome the fragmentation of human knowledge ${ }^{20}$. The results of the present study demonstrate that the students have an understanding that working in the public healthcare system requires new skills 
beyond the individual clinical actions carried out in the oral cavity.

Just under half of the students (45.5\%) stated that they did not feel prepared for work in the public healthcare system. Multivariate Poisson Regression reveals that this variable was associated with the study semester $[\mathrm{p}<0.001$; PR (95\%CI): 2.42 (1.66-3.52)] (Table 3). The proportion of affirmative responses to the question of not being well-prepared for work in the public healthcare system among the students in the first to fifth semester was 2.42 -fold greater than among the students in the sixth to tenth semesters, revealing that students in the final semester feel more prepared for the public healthcare system. Other socio-demographic variables were not associated with students' related abilities for working in the public healthcare system. There is a need to revise the teaching model for the initial semester, as these students reported a lack of knowledge regarding the public healthcare system. It may be stated that there is a dichotomy between theory and practice in teaching classes involving social issues, the content of which is compartmentalized and does not favour the integration of teaching and service. Among the students who reported having experience in the public healthcare system, $68.3 \%$ stated that the experience was either great or good.
A minority of the students (5.4\%) stated that they were not in favour of greater experience in the public healthcare system and the concept of teaching/service integration. This finding was associated with gender [ $\mathrm{p}=0.022$; PR $(95 \% \mathrm{CI}): 3.69$ (1.21$11.36)]$ and age [p=0.031; PR (95\%CI): 3.99 (1.1414.04)] (Table 4). Males were 3.69-fold more likely to be unfavourably disposed to teaching/service integration and younger students were 3.99-fold more likely to be unfavourably disposed to this integration than students over 21 years of age.

The students were asked whether they would take the classes on Collective/Public Health (public system, FHP) if they were optional and $83.3 \%$ said "no". In the qualitative approach, the interviews revealed that public healthcare in the final semesters offers good prospects for dentistry, which is included in the FHP.

I see collective healthcare as a very good future [...]. It has created a larger market and has established oral healthcare teams. (S18)

As for negative opinions about the disciplines of public health, there is a need for further comprehension on the rejection of this theme. One possibility would be a limited view of students on the idea that this topic is purely theoretical in the early periods of the course. Although in later periods there is an attempt to combine theoretical and practical knowledge in a contextualized

Table 3. Students' self-evaluations regarding their ability to work in the public healthcare system; univariate and multivariate Poisson regression with robust variance

\begin{tabular}{|c|c|c|c|c|c|c|}
\hline \multirow[b]{2}{*}{ Variables } & \multicolumn{4}{|c|}{ Working in the public healthcare system } & \multirow{2}{*}{$\begin{array}{c}\mathrm{PR}(95 \% \mathrm{CI})^{\mathrm{a}} \\
\text { univariate }\end{array}$} & \multirow{2}{*}{$\begin{array}{l}\text { PR }(95 \% C I)^{a} \\
\text { multivariate }\end{array}$} \\
\hline & Pre & pared & Not & repared & & \\
\hline \multicolumn{7}{|l|}{ Semester ${ }^{*}$} \\
\hline $6^{\text {th }}$ to $10^{\text {th }}$ & 90 & $75.0 \%$ & 30 & $25.0 \%$ & 1 & 1 \\
\hline $1^{\text {st }}$ to $5^{\text {th }}$ & 32 & $30.8 \%$ & 72 & $69.2 \%$ & $\begin{array}{c}2.77(1.98-3.88) \\
p<0.001^{b}\end{array}$ & $\begin{array}{l}2.42(1.66-3.52) \\
p<0.001^{b}\end{array}$ \\
\hline \multicolumn{7}{|l|}{ Gender ${ }^{*}$} \\
\hline Female & 75 & $54.0 \%$ & 64 & $46.0 \%$ & 1 & - \\
\hline Male & 47 & $55.3 \%$ & 38 & $44.7 \%$ & $\begin{array}{c}0.97(0.72-1.31) \\
p=0.846^{b}\end{array}$ & - \\
\hline \multicolumn{7}{|l|}{ Age $(\text { year })^{*}$} \\
\hline 22 and over & 93 & $66.9 \%$ & 46 & $33.1 \%$ & 1 & 1 \\
\hline 17 to 21 & 29 & $34.1 \%$ & 56 & $65.9 \%$ & $\begin{array}{c}1.99(1.50-2.64) \\
p<0.001^{b}\end{array}$ & $\begin{array}{l}1.34(0.99-1.81) \\
p=0.060^{b}\end{array}$ \\
\hline \multicolumn{7}{|l|}{ Origin $^{*}$} \\
\hline North of State & 104 & $53.3 \%$ & 91 & $46.7 \%$ & 1 & - \\
\hline Other Places & 18 & $62.1 \%$ & 11 & $37.9 \%$ & $\begin{array}{c}0.81(0.50-1.33) \\
p=0.406^{b}\end{array}$ & - \\
\hline
\end{tabular}

${ }^{a}$ PR $\left(95 \%\right.$ CI) - Prevalence Ratio (95\% confidence interval). ${ }^{b}$ Wald Test. ${ }^{*}$ There was missing information for 5 individuals 
Table 4. Students' opinions on including more activities of teaching/service integration; univariate and multivariate Poisson regression with robust variance

\begin{tabular}{|c|c|c|c|c|c|c|}
\hline \multirow[b]{2}{*}{ Variables } & \multicolumn{4}{|c|}{ More activities of teaching/service integration } & \multirow{2}{*}{$\begin{array}{c}\mathrm{PR}(95 \% \mathrm{CI})^{\mathrm{a}} \\
\text { univariate }\end{array}$} & \multirow{2}{*}{$\begin{array}{l}\mathrm{PR}(95 \% \mathrm{CI})^{\mathrm{a}} \\
\text { multivariate }\end{array}$} \\
\hline & & es & & & & \\
\hline \multicolumn{7}{|l|}{ Semester } \\
\hline $6^{\text {th }}$ to $10^{\text {th }}$ & 111 & $93.3 \%$ & 8 & $6.7 \%$ & 1 & - \\
\hline $1^{\text {st }}$ to $5^{\text {th }}$ & 100 & $96.2 \%$ & 4 & $3.8 \%$ & $\begin{array}{c}0.57(0.18-1.85) \\
\mathrm{p}=0.350^{\mathrm{b}}\end{array}$ & - \\
\hline \multicolumn{7}{|l|}{ Gender } \\
\hline Female & 135 & $97.1 \%$ & 4 & $2.9 \%$ & 1 & 1 \\
\hline Male & 76 & $90.5 \%$ & 8 & $9.5 \%$ & $\begin{array}{c}3.31(1.03-10.64) \\
p<0.001^{b}\end{array}$ & $\begin{array}{l}3.69(1.21-11.36) \\
p=0.022^{b}\end{array}$ \\
\hline \multicolumn{7}{|l|}{ Age (year) } \\
\hline 22 and over & 133 & $97 \%$ & 4 & $2.9 \%$ & 1 & 1 \\
\hline 17 to 21 & 78 & $90.7 \%$ & 8 & $9.3 \%$ & $\begin{array}{c}3.19(0.99-10.31) \\
p=0.052^{b}\end{array}$ & $\begin{array}{l}3.99(1.14-14.04) \\
\mathrm{p}=0.031^{\mathrm{b}}\end{array}$ \\
\hline \multicolumn{7}{|l|}{ Origin } \\
\hline North of State & 181 & $93.8 \%$ & 12 & $6.2 \%$ & 1 & - \\
\hline Other Places & 30 & $100 \%$ & 0 & $0 \%$ & $\begin{array}{c}0.86(0.81-0.91) \\
p=0.160^{b}\end{array}$ & - \\
\hline
\end{tabular}

${ }^{\mathrm{a}} \mathrm{PR}(95 \% \mathrm{CI})$ - Prevalence Ratio (95\%confidence interval). ${ }^{\mathrm{b}}$ Wald Test. ${ }^{*}$ There was missing information for 6 individuals

view, there is a need to reevaluate the teaching strategies to improve the processes of teaching and learning and adherence to this theme.

The results of the present study reveal a worrisome situation: $83.3 \%$ would not take Collective/Public Health classes if they were optional and only $5.6 \%$ would specialize in this field. Nonetheless, $89.1 \%$ intend to work in the public healthcare system. Yet again, the results reveal the perception of the public system as a residual job option. Furthermore, difficulties remain in breaking from the distorted view that the public sector does not require technologies of high complexity for exercising a profession in primary care - that specific knowledge is not required for working in this field. A previous study ${ }^{32}$ sought to understand conceptions regarding collective healthcare among professionals and concluded that most only see it from the standpoint of disease prevention for the part of the population that is excluded from private healthcare services.

Regarding the use of the services offered by the public healthcare system, the students reported that if they needed dental care, only $4.0 \%$ would seek public services. In the qualitative approach, the public system was criticized for the precariousness of working conditions and the limited offer of services. The literature states that the
Brazilian public healthcare system is considered incomplete, as it has not been able to overcome the biomedical model that is predominant in public health policies in Brazil2 ${ }^{28}$.

The working situation is very precarious; there are few perishable materials. Sometimes a dentist is unable to work due to a lack of materials. The equipment is [...] old and worn out. (S4)

In the public sector, the quantitative aspect supersedes the qualitative aspect of care $^{33}$. Along with a lack of materials and offering unsatisfactory working conditions, the students perceive that the public sector does not offer integrated care and therefore does not ensure its constitutional principles.

I wanted to perform a restoration, but had to extract the tooth due to the insufficient working conditions; [...] we get frustrated.(S9)

The perceptions of a lack of integrality in healthcare and the lack of quality in the services offered by the public system may explain the low percentage of students in the present study who use public healthcare services $(4.0 \%)$. While part of the population does not seek public services because they have no faith in the quality of such services, many individuals have no access to public healthcare. The low coverage of dental services has always been a public health concern in Brazil. 
Historically, the inclusion of dentistry in the public sector was related to care for the needy and a predominance of exodontias ${ }^{33}$.

Public health efforts have concentrated on offering access to quality dental services for every Brazilian citizen. The guidelines of the National Oral Health Policy propose organizing oral health within the realm of public healthcare on all levels and based on integrality ${ }^{29}$. The National Basic Healthcare Policy determines the infrastructure and resources necessary for the actions, thereby ensuring efficacy in public healthcare ${ }^{34}$. Thus, it may be said that public health policies are being implemented in order to offer dental services within the public healthcare system, with greater quality and integrality. Despite the undeniable public efforts, the perceptions of the students, which are the fruit of historical constructions, do not change quickly and may compromise the building of the Brazilian public healthcare system.

\section{Conclusions}

Contact with the social context through teaching/service integration in the advanced semesters of the dental course appears to contribute towards the development of new professional skills for working in the public sector. However, the students' perceptions have revealed contradictions, considering the low value they have attributed to the classes on Collective/Public Health and their perception of the public system as a residual job option, location for training and to earn money to invest in private practice.
There is therefore a need to undertake further efforts to tailor dental training to meet the real demands of the public health sector, which is still seen as a means of exploitation and failure. The public health system is being presented as a place where graduates can acquire new skills and competencies to work in the public sector, offering the possibility of combining these with their clinical skills and professional practice. However, this seems not to take account of increasing social awareness, since individuals revealed some bias against a professional future working in the public sector.

\section{Collaborations}

SM Costa, MF Silveira, SJA Durães, MHNG Abreu and PRF Bonan participated equally in all stages of preparation of the article. 


\section{References}

1. Cornwall A, Shanklanda A. Engaging citizens: lessons from building Brazil's national health system. Soc Sci Med 2008; 66(10):2173-2184.

2. Gil CRR. Human resources training in family health: paradoxes and perspectives. Cad Saude Publica 2005; 21(2):490-498.

3. Skelton J, Mullins MR, Kaplan AL, West KP, Smith TA. University of Kentucky community-based field experience: program description. J Dent Educ 2001; 65(11):1238-1242.

4. Bernabé E, Bernal JB, Beltrán-Neira RJ. A model of dental public health teaching at the undergraduate level in Peru. J Dent Educ 2006; 70(8):875-883.

5. Bernabé E, Ludeña MA, Beltrán-Neira RJ. Self-perceived public health competency among recent dental graduates. J Dent Educ 2006; 70(5):571-579.

6. Razak IA, Latifah RR, Jaafar N, Abu Hassan MI, Ab Murat N. Assessing the competence of Malaya dental graduates: employers' and graduates' perceptions. J Dent Educ 2008; 72(3):364-369.

7. Lampert JB. Na transição paradigmática da educação médica: o que o paradigma da integralidade atende que o paradigma flexneriano deixou de lado. Boletim da ABEM. [serial on the Internet] 2003; 31. [cited 2006 Mar 23]. [about 3p]. Available from: http://www.abem-educmed.org.br/caderno

8. Brasil. Ministério do Trabalho. Registros Administrativos do Cadastro Geral dos Empregados e Desempregados. Brasília: Ministério do Trabalho; Série 1990 a 2000 .

9. Brasil. Ministério da Saúde. Ministério da Educação. Programa Nacional de Reorientação da Formação Profissional em Saúde. PRÓ-SAÚDE. Brasília: MS; 2005.

10. Sousa MF, Hamann EM. Programa Saúde da Família no Brasil: uma agenda incompleta? Cien Saude Colet 2009; 14(Supl. 1):1325-1335.

11. Spink MJ. O conceito de representação social na abordagem psicossocial. Cad Saude Publica 1993; 9(3):300-308.

12. Nutbeam D. Evaluation health promotion-progress, problems and solutions. Health Promot Int 1998; 13(1):27-44

13. DeSilets LD. Needs assessment: an array of possibilities. J Contin Educ Nurs 2007; 38(3):107-112.

14. Bower E, Scambler S. The contributions of qualitative research towards dental public health practice. Community Dent Oral Epidemiol 2007; 35(3):161-169.

15. Bardin L. Análise de conteúdo. Lisboa: Edições 70; 1979.

16. Minayo MCS. O desafio do conhecimento: pesquisa qualitativa em saúde. 9a ed. São Paulo, Rio de Janeiro: Hucitec, Abrasco; 2006.

17. Griep RH, Chor D, Faerstein E, Lopes C. Test-retest reliability of measures of social network in the "PróSaúde” Study. Rev Saude Publica 2003; 37(3):379-385.

18. Jick TD. Mixing quantitative and qualitative methods triangulation in action. Adm Sci Q 1979; 24(4): 602-611.
19. Costa SM, Durães SJA, Abreu MHNG. Feminization of the odontology course at the State University of Montes Claros - Unimontes, Brazil. Cien Saude Colet 2008; 15(Supl. 1):1865-1873.

20. Araújo MBS, Rocha PM. Teamwork: a challenge for family health strategy consolidation. Cien Saude Colet 2007; 12(2):455-464.

21. Jover M, Doudoux D, Deveaux E. Representations of the dental surgery profession and the motivations given by second-year French students for applying for dental surgery. Eur J Dent Educ 2006; 10(1):2-9.

22. Carvalho CL. Dentistas Práticos no Brasil: história de exclusão e resistência na profissionalização da Odontologia Brasileira. [tese]. Rio de Janeiro: Escola Nacional de Saúde Pública da Fundação Oswaldo Cruz; 2003.

23. Travassos C, Viacava F, Fernandes C, Almeida CM. Social and geographical inequalities in health services utilization in Brazil. Cien Saude Colet 2000; 5(1): 133-149.

24. Falasco RF, Robinson E, Faja BW. Problems encountered by recent graduates in establishing dental practices. J Mich Dent Assoc 1990; 72(1):15-19.

25. Medeiros UV. Experiências inovadoras no ensino de Odontologia. Odontólogo Moderno 1997; 24(1):9-12.

26. Ashley FA, Gibson B, Daly B, Lygo-Baker S, Newton JT. Undergraduate and postgraduate dental students' reflection on learning: a qualitative study. Eur J Dent Educ 2006; 10(1):10-19.

27. Bastos JRM, Aquilante AG, Almeida BS, Lauris JRP, Bijella VT. Análises do perfil profissional de cirurgiões-dentistas graduados na Faculdade de Odontologia de Bauru - USP entre os anos de 1996 e 2000. J Appl Oral Sci 2003; 11(4):283-289.

28. Starfield B, Shi L, Macinko J. Contribution of primary care to health systems and health. The Milbank Q 2005; 83(3):457-502.

29. Brasil. Ministério da Saúde. Secretaria de Atenção à Saúde. Departamento de Atenção Básica. Coordenação Nacional de Saúde Bucal. Diretrizes da Política Nacional de Saúde Bucal. Brasil: Ministério da Saúde, 2004.16p. [Internet site].[cited Aug 10 2006]. Available from: http://www.saude.gov.br

30. Brasil. Conselho Nacional de Educação. Câmara de Educação Superior. Resolução CNE/CES Diretrizes Curriculares Nacionais para formação em odontologia, de 19 de fevereiro de 2002. Brasil: Conselho Nacional de Educação, 2002. 5p [Internet site]. [cited Nov 14 2003]. Available from: http://www.mec. gov.br

31. Sanchez HF, Drumond MM, Vilaça EL. The Family Health Program (FHP) and human resources: perceptions of students from two different dentistry schools. Cien Saude Colet 2008; 13(2):523-531.

32. Melo MB. Saúde Coletiva e pós-graduação em Odontologia. RBPG 2005; 2(3):55-74.

33. Freitas CHSM. Dilemas no exercício profissional da Odontologia: a autonomia em questão. Interface Comunic Saúde Educ 2007; 11(21):25-38. 
34. Brasil. Ministério da Saúde. Secretaria de Atenção à Saúde. Departamento de Atenção Básica. Política Nacional de Atenção Básica/Ministério da Saúde, Secretaria de Atenção à Saúde. Departamento de Atenção Básica. Brasil: Ministério da Saúde, 2006. 70p [Internet site]. [cited Dec 18 2007]. Available from: http://www.saude.gov.br

Artigo apresentado em 24/04/2010

Aprovado em 19/06/2010

Versão final apresentada em 01/07/2010 